\title{
An Analytical Approach to Understand Customer Relationship Management in Indian Banking Sector from the Perspective of Customers
}

\author{
Sanjeev Bansal ${ }^{*}$ and GarimaMalik ${ }^{\dagger}$
}

\begin{abstract}
In recent years, significant developments have been experienced in the banking sector. With the improved technology, banks have become institutions that offer services for 24 hours through telephone, internet and ATMs. Besides the classic banking services, they have taken over a number of activities such as automatic billing, which facilitate the lives of the customers. To maximize lifetime profitability from valued customers, banks have changed traditional silo mindset and have adopted Customer Relationship Management (CRM) techniques.

This paper examines the relationship between the customer loyalty and CRM in National Capital Region of India. Methodology of the paper has been designed such that, it abstracts the scales into 5 dimensions related to CRM of banks. This paper uses regression analysis to arrive at a model which explains customer loyalty. This paper also provides insights for the banks which adopt CRM at a strategic standpoint as well as operational standpoint and implement a customer - centric vision.
\end{abstract}

Keyword: Customer relationship management, Banking sector, Customer services, Customer lifetime value.

"Director of Amity Business School, Panchgaon, Manesar, Gurgaon, Haryana, India;

tProfessor, Amity Business School, Panchgaon, Manesar, Gurgaon, Haryana, India; : gkmalik@amity.edu 


\section{Introduction}

Whether enterprises can make their current customers loyal depends on whether they can manage the customer relationships well. As customers have grown to be more conscious consumers, enterprises have to pay the prices of the errors and faults they do in customer relationship. The phrase Customer Relationship Management (CRM) appeared in literature after the evolution in relationship marketing philosophy. Berry (1983) defined relationship marketing as attracting, maintaining and enhancing the customers' relationships in multiservice organizations. After a few decades, the evolution in relationship marketing philosophy changed the word relationship marketing to CRM. According to Brown (2000) CRM is a process of acquiring new customers, retaining the existence customers, and at the same time understanding, anticipating and managing the needs of an organization's current and potential customers. Furthermore, Mylonakis (2009) described CRM as an innovative process to create a long term relationship and gaining trust. Further, a clear vision of CRM along with appropriate strategies if applied in banking sector has been found beneficial in maintaining the customer service quality, customer satisfaction and customer retention which ultimately leads to the growth of the organization and profitability (Bansal and Sharma, 2008). Girdhar (2009) observed that by satisfying the internal customers and building good relationship with them, the relationship with the external customers can also be retained and satisfied by the banks. Kumar \& Rajesh (2009) reveals that any bank that wishes to either grow in size of its banking operation or improve its profitability must consider the challenges affecting its customer relationship. The challenge before the banks is not only to obtain updated information from each customer, but also to use the information to determine the best time to offer the most relevant products (Lau et al., 2003). It is also important to understand that if customers bring in profits for the bank, it becomes imperative for the bank to provide excellent services to those customers, otherwise they switch to other banks (Ray, 2007). Service quality in banking implies consistently anticipating and satisfying the needs and expectations of customers. 
Parasuraman et al. (1985) also hold the view that high quality service gives credibility to the field sales force and advertising, stimulates favorable word-of-mouth communications, enhances customers' perception of value, and boosts the morale and loyalty of employees and customers alike. Puccinelli (1999) looks the financial services industry as entering a new era where personal attention is decreasing because the institutions are using technology to replace human contact in many application areas. Over the last few decades, technological evolution has highly affected the banking industry (Sherif, 2002). In today's competitive banking industry, customers have to make a choice among various service providers by making a trade-off between relationships and economies, trust and products, or service and efficiency (Sachdev et al., 2004). Roger Hallowell (1996) conducted a research on customer satisfaction, loyalty, and profitability and found that as compared to public sector bank, customers of private sector bank have higher levels of satisfaction. CRM is a key factor to create a superior customer experience. It manages the customer relationship by creating a clear understanding (Know), by developing services and products based on the added value for target groups (Target), then enabling the actual sale and delivery of services and products through the selected channels (Sell), and developing long term profitable relationships with customers through better after sales services (Service) (Hussain, et.al., 2009). Many researches have been done in various industries including banking sector that focuses on customer oriented services (Ndubisietal., 2007; Rootman et al., 2008; and Duttaand Dutta, 2009). The literature on CRM suggests that banks should consider the customer relationship life cycle (Dwyer et al., 1987). In general, there are three core phases: customer acquisition, customer enhancement, and customer recovery (refer to fig. 1). The acquisition phase describes the initiation of a customer-bank relationship. 


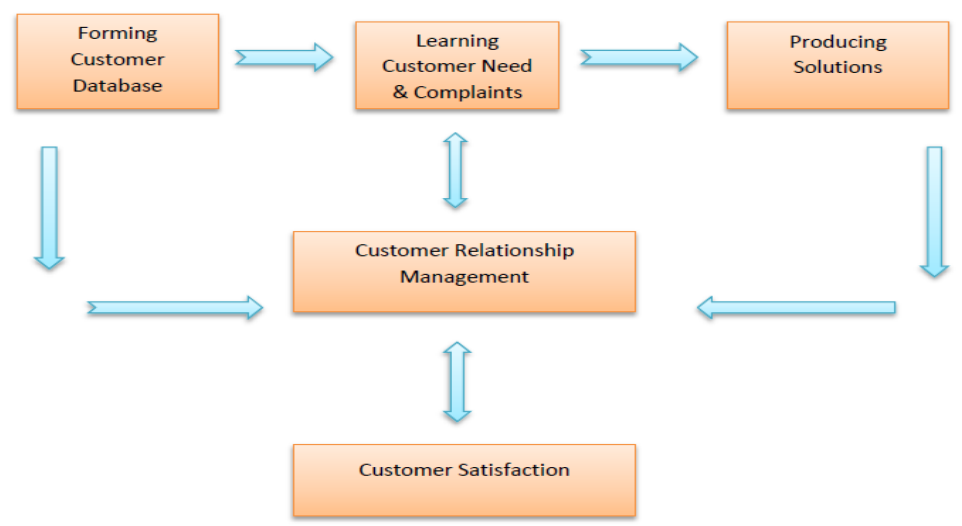

Fig1: Framework of customer relationship management

\section{Customer relationship management in banking sector}

Enterprises produce benefits of form, time, place and property that satisfy the customers' demands thanks to the goods and service. Forming and marketing of the goods and services that satisfy the customer demands is the basis of producing benefit (Altnatas, 2000). For any customer, satisfaction depends on the comparison between what is offered to him with his own expectations. If products or services offered suits the expectations, the customer is satisfied, but if it does not suit, he is not satisfied. If what is offered is above the expectations, the customer is highly satisfied and pleased (Kotler, 2005). For example, if the real performance of a product or service in a bank is below the expectations, the result is dissatisfaction, but if it is equal or higher, customer satisfaction is achieved (Gurbuz 2008).

In recent years, especially in banking sector, where there is a strong competition, customer satisfaction has gained a good deal of importance. It may be very easy to let another bank capture a displeased customer. To raise the customer satisfaction to the highest level and retain their customers, the banks are to attach importance to customer relationship management. The benefits gained from customer relationship management and its success depends on whether they follow the technological developments closely and make investments to this end. It also depends on the 
choice of right CRM strategies by the banks. There are four important steps in adopting customer relationship management strategy in the banks. The first step is "planning and targeting". It is necessary to make a documented strategy stating how customer relationships are to be directed. The second step, "design", allows in preparing the prime designs supporting the bank strategy. A lot of banks ignore this step, but it is important for coordination and thus success. The third step is "building". At this stage, projects for changes are started. The fourth step is "running and developing the programmes".

\section{Research Objectives}

a) To assess the role of Customer Relationship Management in Banking Sector

b) To assess the perception of customers towards the implementation of CRM in banks.

c) To assess the factors leading to customer loyalty with respect to the dimensions of bank's CRM.

\section{Research Methodology}

The research methodology for the present study was based upon descriptive research design. Stratified non-probability sampling method was used, which involves the sample being drawn from that part of the population which is close to hand. In this study, the target populations were men and women of different age groups, who regularly watch Hindi movies. Responses were collected from 100 respondents from the NCR (National Capital Region) of India, as NCR is the headquarters to many banks and contain the right mix of desired sample. In research process firstly, respondents were made aware about the purpose of study and then they were requested to mark their unbiased responses. The questionnaire was pre-tested on 20 respondents and later, minor changes were incorporated in the questionnaire. Further, the data was categorized into two parts i.e. primary data (collected through questionnaires) and secondary data (collected with the help of newspapers, magazines, industry reports and various other journals) for 
statistical analysis. The questionnaire consisted ordinal scale questions to know the priority of each item among the group (1 being the best rank and 5 being the least), interval scale was employed in "Likert scale type" to extract data with a magnitude and nominal scale was employed to store demographic profile of the respondents. The primary data was analyzed using SPSS software for data reduction through factor analysis and the same was depicted using bar charts, factor analysis, regression analysis, etc.

\section{Analysis based on quantitative data}

\section{Use of bank branch as per location:}

Table 1 showcases the relation of the respondent w.r.t. the location of the bank branch. It can be inferred that a good mix of respondents have been selected for the study, who are distributed across the targeted region.

Table 1: Location of the bank branch

\begin{tabular}{|l|c|c|}
\hline \multicolumn{1}{|c|}{ Area } & Frequency & Percent \\
\hline South Delhi & 26 & 26 \\
\hline North Delhi & 22 & 22 \\
\hline East Delhi & 24 & 24 \\
\hline Noida & 17 & 17 \\
\hline Ghaziabad & 11 & 11 \\
\hline Total & 100 & 100 \\
\hline
\end{tabular}

Respondents selected for this study are fairly scattered across NCR (National Capital Region) and this distribution ensures in delivering effective insights out of proceeding analysis.

\section{Frequency of bank branch visits:}

a. Visited bank branch in the last week: Respondents were enquired, whether they have utilized any of the banking services in the last week through a bank branch. 


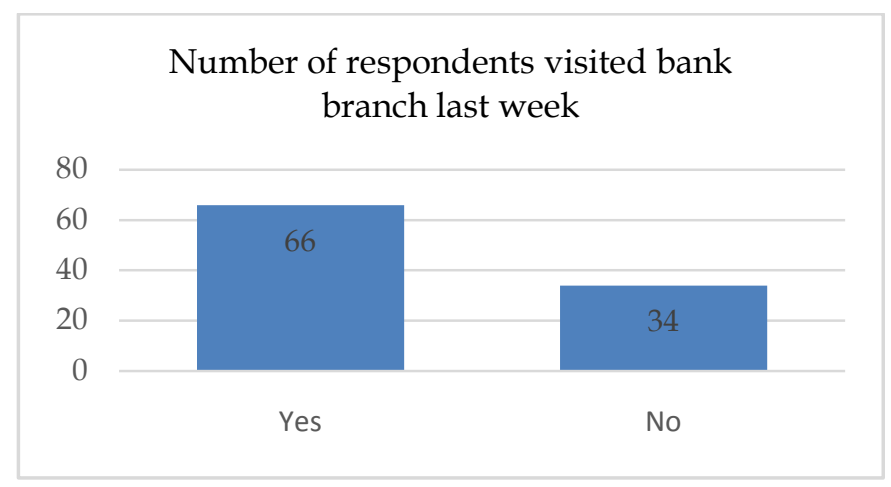

Fig 2: Number of respondents visited bank branch last week

From figure 2 it is evident that, 66 respondents visited their bank branch in last week, whereas 34 people did not visit their branch last week. Majority of the respondents' visit to their bank branch last week would make data more usable and relevant for study of their response towards the bank's CRM.

b. No. of visits to a bank branch in last 3 months: Respondents were enquired about their no. of visits to bank branch for utilizing the banking services in the last 3 months.

Table 2 Frequency for visiting banks

\begin{tabular}{|l|c|c|}
\hline & Frequency & Percent \\
\hline Never & 25 & 25.0 \\
\hline 1-3 times & 35 & 35.0 \\
\hline 4-9 times & 33 & 33.0 \\
\hline 19 times & 4 & 4.0 \\
\hline 20 or more & 3 & 3.0 \\
\hline Total & 100 & 100.0 \\
\hline
\end{tabular}

Table 2 showcases the frequency of the respondents visiting the bank branch in last 3 months. It can be observed that 25 respondents never visited their branch in last three months, 35 respondents visited their branch 1-3 times, 33 respondents visited their branch 4-9 times, 4 respondents went for 10-19 times and 3 went for more than 20 times. This indicates the appropriate mix of the respondents experiencing the branch banking as well as internet banking for this study. 


\section{Knowledge of bank's products \& Services (Bank employee perspective)}

Respondents were asked to rate the bank employees' knowledge of the banking products on the Likert type scale based upon their interaction during their bank branch visit.

Table 3: Knowledge of products

\begin{tabular}{|l|c|c|}
\hline \multicolumn{1}{|c|}{ Parameters } & Frequency & Percent \\
\hline Very Satisfied & 43 & 43 \\
\hline Satisfied & 47 & 47 \\
\hline Neutral & 5 & 5 \\
\hline Dissatisfied & 2 & 2 \\
\hline Very Dissatisfied & 3 & 3 \\
\hline Total & 100 & 100 \\
\hline
\end{tabular}

Table 3 showcases that, $47 \%$ customers are satisfied with the bank employee's knowledge of products \& services, $43 \%$ very satisfied, $5 \%$ stayed neutral. Whereas $3 \%$ very dissatisfied and $2 \%$ dissatisfied about the bank employee's knowledge regarding banking products. It can be inferred that most of the respondents were positive that bank employees know about the banking products they are dealing with and respondents are satisfied with their knowledge level.

\section{Factor Analysis: Different Dimensions of CRM in Banks}

To narrate the variable in different dimensions of customer relationship management in banks, a factor analysis has been administered.21 item scale has been subjected to KMO Measure and Bartlett's Test. The KMO measure of sampling adequacy is 0.866 , which is greater than 0.5 , which is the recommended value for acceptance of results of factor analysis, by Kaiser (1974) and Bartlett's test of sphericity was significant $\left(\chi^{2}=1.045 \mathrm{E} 3, \mathrm{p}<.05\right)$. However, low p-value of the Bartlett's test of sphericity confirms the usefulness of the factor analysis of the 21 items in the scale.

Table 4: KMO Test

\begin{tabular}{|l|l|}
\hline Kaiser-Meyer-Olkin Measure of Sampling Adequacy & 0.866 \\
\hline Barlett" "s Test of Sphericity Approx. Chi-Square & 1.045 \\
\hline df & 210 \\
\hline Sig & 0.00 \\
\hline
\end{tabular}


Table 5: Total Variance Explained

\begin{tabular}{|c|c|c|c|c|c|c|}
\hline 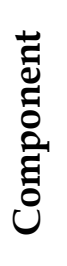 & 胥 & 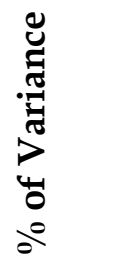 & 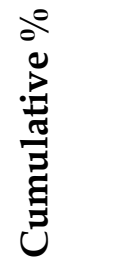 & 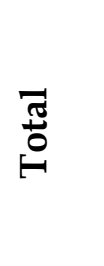 & 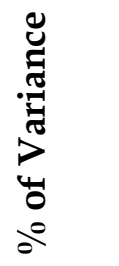 & 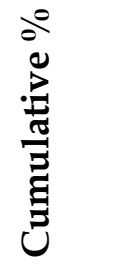 \\
\hline 1 & 6.563 & 31.252 & 31.252 & 5.020 & 23.907 & 23.907 \\
\hline 2 & 1.963 & 9.349 & 40.601 & 2.380 & 11.334 & 35.241 \\
\hline 3 & 1.443 & 6.872 & 47.473 & 2.229 & 10.615 & 45.857 \\
\hline 4 & 1.233 & 5.871 & 53.344 & 1.411 & 6.721 & 52.578 \\
\hline 5 & 1.153 & 5.489 & 58.833 & 1.314 & 6.255 & 58.833 \\
\hline
\end{tabular}

Note: Extraction Method: Principal Component Analysis Source: Primary Data

Table 5: Principal components analysis was used because the primary purpose was to identify and compute composite scores for the factors underlying the dimensions of CRM in banks. Varimax rotation was used to measure the individual factor loadings and the results suggest that the Eigen value, for the extracted 5 factors, was greater than recommended level of 1 . This reveals that from the 21 items included in factor analysis, 5 dimensions were extracted and emerged with a cumulative variance of 58.833 per cent.

Table 6 Rotated Component Matrix

\begin{tabular}{|c|c|c|c|c|c|}
\hline Factors & 1 & 2 & 3 & 4 & 5 \\
\hline Knowledge about banking services & 0.715 & & & & \\
\hline Confidence in bank services & 0.671 & & & & \\
\hline $\begin{array}{l}\text { Personalized service to meet } \\
\text { customer's needs }\end{array}$ & 0.867 & & & & \\
\hline $\begin{array}{l}\text { Knowledge about current trends } \\
\text { related to banking }\end{array}$ & 0.568 & & & & \\
\hline $\begin{array}{l}\text { Ready to listen the voice of customer } \\
\text { and showing respect towards the } \\
\text { customers }\end{array}$ & 0.789 & & & & \\
\hline Help me to design my portfolio & 0.615 & & & & \\
\hline Flexi timing of banking operations & 0.888 & & & & \\
\hline
\end{tabular}




\begin{tabular}{|l|c|c|c|c|c|}
\hline \multicolumn{1}{|c|}{ Factors } & $\mathbf{1}$ & $\mathbf{2}$ & $\mathbf{3}$ & $\mathbf{4}$ & $\mathbf{5}$ \\
\hline Ready to welcome customer queries & 0.718 & & & & \\
\hline $\begin{array}{l}\text { Providing proactive information } \\
\text { about services }\end{array}$ & 0.554 & & & & \\
\hline $\begin{array}{l}\text { Offering timely and trust worthy } \\
\text { information }\end{array}$ & 0.512 & & & & \\
\hline Proactive in serving customer's needs & & 0.819 & & & \\
\hline Grievance handling & & 0.718 & & & \\
\hline $\begin{array}{l}\text { Bank commitments to customers and } \\
\text { timely fulfil }\end{array}$ & & 0.888 & & & \\
\hline Offers advice on how to invest & & 0.532 & & & \\
\hline Fulfil its obligation to customer & & & 0.748 & & \\
\hline Bank words and promises are reliable & & & 0.623 & & \\
\hline Consistency in banking services & & & & 0.819 & \\
\hline Informing about new banking service & & & & & 0.617 \\
\hline $\begin{array}{l}\text { Concerned with security of } \\
\text { transaction }\end{array}$ & & & & & 0.568 \\
\hline
\end{tabular}

Note: Extraction method: Principal component analysis, Rotation method: Varimax with Kaiser Normalization, Rotation converged in 7 iterations. The rotated component matrix shows that knowledge about market trends, confidence with bank services, personalized service to meet customer needs, knowledge about banking services, showing respect to customers, helping customers to plan their investment, Bank is flexible when its service are changed, openly discussing solution when problems arise, providing effective sales promotion can be grouped into first factor. This factor can be named as competence. Providing timely and trust worthy information, flexibility in serving customer needs, bank helping to avoid potential conflict, bank fulfills its promises, providing advice on how to invest can be grouped into second factor. This can be named as relationship communication. Bank tries to solve conflict instead of creating problems, providing accurate information, fulfill its obligation to customers, can be put under third factor named caring. Bank's words and promises are reliable, consistent in providing services can be grouped into fourth factor and can be labeled as trust. Informing about new banking services and concerned with security of transactions be put under fifth factor, which can be named as shared information. 


\section{Multiple Regression Analysis}

To identify whether different dimensions of CRM has strong impact on customer loyalty, multiple regression was used.

Table 7: Regression Table

\begin{tabular}{|c|c|c|c|c|c|}
\hline \multicolumn{6}{|c|}{$\begin{array}{l}\text { Contribution of variables in the dimensions of trust Dependent variable: } \\
\text { customer loyalty }{ }^{\text {ee }} \text { Scores }(y)\end{array}$} \\
\hline 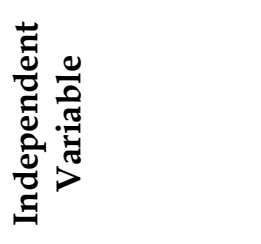 & 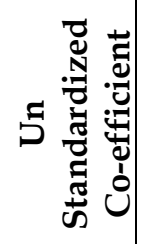 & 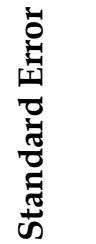 & 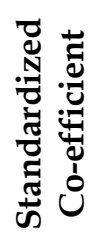 & $\frac{\substack{\frac{0}{2} \\
\frac{1}{2}}}{+1}$ & \\
\hline Constant (y) & 1.829 & 0.356 & - & 5.130 & 0.000 \\
\hline $\begin{array}{l}\text { Bank words } \\
\text { and promises } \\
\text { are reliable }(\mathrm{X} 1)\end{array}$ & 0.531 & 0.078 & 0.502 & 6.841 & 0.000 \\
\hline
\end{tabular}

Contribution of variables in the dimensions of trust Dependent variable: customer loyalty" Scores (y)

\begin{tabular}{|c|c|c|c|c|c|}
\hline 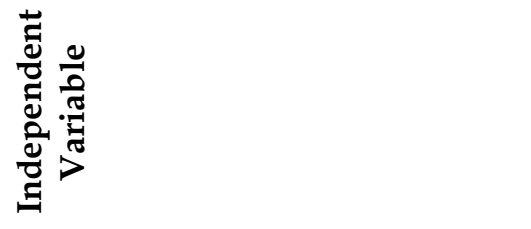 & 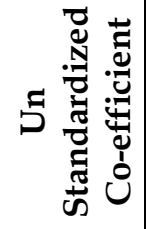 & 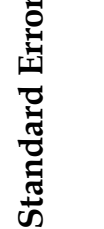 & 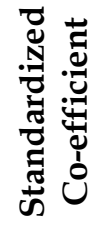 & 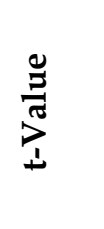 & 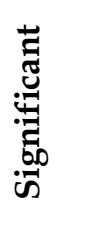 \\
\hline $\begin{array}{l}\text { Consistence in providing services } \\
\text { (X2) }\end{array}$ & 0.062 & 0.056 & 0.082 & 1.112 & 0.268 \\
\hline
\end{tabular}

Note: Multiple R 0.514, F-Value 24.590: d.f $(2,137)$ p < 0.05: and R2 $=0.264$

The above table explains contribution of trust dimensions of customer relationship management to customer Loyalty.

$Y=1.829+0.531(\mathrm{X} 1)+0.62(\mathrm{X} 2)$ Where $\mathrm{Y}$ is the estimated customer Loyalty Score.

The above equation revealed the variables of trust such as bank words and promises are reliable, consistent in providing services. On an average, if the perception score of trust changes by 1 unit, 
there will be 0.531 unit increase in customer loyalty, other variable being remain constant similarly the multiple $\mathrm{R}$ of 0.514 revealed that there existsa relationship of 51 percent between trust and customer loyalty. Similarly R2 indicates 0.264 change in trust explained and variation of 26 percent in customer loyalty. The relative importance of variables in predicting trust can be determined by comparing beta co-efficient. Values of Beta are 0.502 , 0.082 respectively for bank words and promises are reliable, and consistent in providing services. This shows that among all aspect of trust, bank words and promises are reliable had most powerful impact on customer loyalty.

\section{Conclusions}

Bankers can no longer view the customer from the perspective of specific products or a snapshot in time. Banks that carry out advertisement and presentation activities besides a variety of services offered to their customers undergo high costs for the sake of competition. However, expensive advertisement campaigns are not adequate in competition, for there is a serious need for high technologic substructure and automation support. It is of significance that banks should make one-to-one and individualized relationships with their customers, offer privatized services and determine the customers' needs. To collect information about the customer and update them are among the important milestones of customer relationship management. This study has successfully showcased that customer loyalty towards the bank can be successfully managed through following dimensions of bank's CRM:

- Competence

- Relationship communication

- Care

- Trust

- Information sharing

Research results show that not only collecting data about the customers but also giving information to them arouses customer loyalty, arousing in the customer a sense ofbeing valued. The fact that banking procedures are fast and customers are not kept 
waiting much are rather important for customer loyalty. The personnel's knowledge of banking and mastery of the subject accelerate the speed of the service given, so any attempt to train the personnel is necessary for customer loyalty. There are two objectives of customer relationship management in the banks. One of them is to gain customers, namely to activate the potential customers, and the other is to keep the number of the existing customers. To this end, customer database should be formed and updated frequently. Even though study indicates that customers perceive the bank staff to be knowledgeable, communication of the personnel with the customers and the use of information systems is a requirement of customer-based understanding and for progressive relationship. Forming and sustaining healthy and longterm customer relationships have become an important means of competition in the banking sector. The attempt to retain the customer affects the success of the banks due to the fact that one-toone communication is achieved with the customer especially in the field of commercial credit and the rate of profitability is taken from the credit customers. In summary, banks' ability to retain their existing customers and gain new customers depends on seamless customer relationship management.

\section{Suggestions and Recommendations}

- Considering customer relationship management can provide numerous benefits for financial institutions. A customer of banks and financial institutions is equal to at least one asset and by using this approach, retention of current customers and encouraging them to future reference is re-underlying to their survival in the midst of competition. According to the results of research, it can be said that deployment of customer relationship management system leads to customer loyalty. And by considering the quality, features and service availability as well as complaints system, following suggestions for improving the customer relationship management systems are offered: 
- Identify hidden needs and expectations of customers and expand the range of services;

- Presence of sufficient knowledge in bank's employees to speed up bank operations;

- Create workgroups or a committee that would deal with reviews, complaints and requests from customers which may require time and cost;

- One of the parameters for employee appraisals should be based on effective implementation of CRM by them;

- The banks should use new technologies to provide newer and faster services consistently to customers.

\section{References}

Bansal, Ipshita and Sharma, Rinku (2008). Indian Banking Services: Achievements and Challenges. The ICFAI University Journal of Services Marketing, Hyderabad. VI (2), 32-43.

Berry, Leonard L (1983). Relationship Marketing in Emerging Perspectives on Services Marketing. American Marketing Association, Chicago, 25-28.

Berry, M.J.A. \&Linoff G.S. (2000). Mastering Data Mining: The Art and Science of Customer Relationship Management. John Wiley \& Sons, Inc.

Brown, S. A. (2000). Customer Relationship Management: A Strategic Imperative in the World of E-Business. Canada: John Wiley \& Sons.

Dutta, K. \& Dutta, A. (2009). Customer Expectations and Perceptions across the Indian Banking Industry and the Resultant Financial Implications. Journal of Services Research, 9, 31-49.

Girdhar, Seema (2009). Building Relationship through Internal Customer: A Study of South Asian Selected Co-Operative Banks With Special Reference to Surat District of Gujarat State. Pranjana - The Journal of Management Awareness, Delhi, 12 (2), 32-43.

Gürbüz, E. (2008). Retail Store Branding in Turkey: It's Effect on Perceived Quality, Satisfaction and Loyalty. Euro MED Journal of Business, 3(3), 290-291.

Holloway, A. (2002). It's All about Relationships. Canadian Business, 75(20).

Kumar M. Ashok and Rajesh R. (2009). Whether Today's Customers are Satisfied? -A Study with Banks. Indian Journal of Marketing, New Delhi, XXXIX (9), 45-53.

Lau K, Wong S, Ma M and Liu C. (2003). Next Product to Offer for Bank Marketers. Journal of Database Marketing, 10(4), 353-368. 
Mylonakis, J. (2004). Bank Market Positioning Maps: Customer Perceptions of Hellenic Financial Services. International Journal of Services Technology and Management, 5(2), 140-150.

Ndubisi, N. O., Wah, C. K., \&Ndubisi, G. C. (2007). Supplier-Customer Relationship Management and Customer Loyalty: The Banking Industry Perspective. Journal of Enterprise Information Management, 20 (2), 222-236.

Parasuraman, A., Zeithaml. V.A. and Berry, L.L. (1985). A Conceptual Model of Service Quality and its Implications for Future Research. Journal of Marketing, 49 (Fall), 41-50.

Puccinelli, B. (1999). Bank Delivery, Service Channels Require More Personal Attention. Bank Systems \& Technology, 36-48.

Ray, B. (2007). An analytical approach to understand customers from the perspective of profit making. Marketing Mastermind. The ICFAI University Press, 52-55.

Rootman, C., Tait, M., \& Bosch, J. (2008). Variables Influencing the Customer Relationship Management of Banks. Journal of Financial Services Marketing, 13(1), 52-62.

Sachdev S. B and Verma H.V. (2004). Relative Importance of Service Quality Dimensions: A Multi-Sectoral Study. Journal of Services Research, 4(1), 59-81. 